\title{
Citizen Journalism and Online Community Media: A Case Study of pwmu.co
}

\section{Jurnalisme Warga dan Media Komunitas Daring: Studi Kasus pada pwmu.co}

\author{
Filosa Gita Sukmono' ${ }^{1}$, Fajar Junaedi ${ }^{1}$ \\ ${ }^{1}$ Study Program of Communication Science, Faculty of Social and Political Science, \\ Universitas Muhammadiyah Yogyakarta, Jl. Brawijaya, Kasihan, Bantul, Yogyakarta \\ 55183, Indonesia \\ *Corresponding author, e-mail: filosa@umy.ac.id
}

\begin{abstract}
One of the most prominent online community media in Muhammadiyah is pwnu.co (https://pwmu.co/) that published by the Regional Office of Muhammadiyah (PWM) East Java. This article departs from an interest of the writing team to find out how citizen journalism-based media management works in the online community media, especially pwmu.co. This study itself uses a case study method by collecting data using in-depth interviews, then selecting informants using purposive sampling or criterion-based selection. In this study, informants were pwmu.co editors, while observations were made by looking carefully at the pwmu.co editorial room. The result demonstrates that community media management executed by pwmu.co accentuates citizen journalism principles and voluntarily actions to resolve their works relating to collecting news. Journalists and reporters in this community are citizen journalist that comes from Muhammadiyah people and they are trained through a series of the workshop by the editors of pwmu.co.
\end{abstract}

Keywords: Online Community Media, Citizen Journalism, Voluntarily, Muhammadiyah.

\begin{abstract}
Abstrak
Salah satu media komunitas daring di Muhammadiyah yang menonjol adalah pwmu.co (https://pwmu.co/) yang dipublikasikan oleh Pengurus Wilayah Muhammadiyah (PWM) Jawa Timur. Artikel ini berangkat dari sebuah ketertarikan penulis untuk mengetahui bagaimana manajemen media berbasis jurnalisme warga bekerja dalam media komunitas daring khususnya pwmu.co. Penelitian ini sendiri menggunakan metode studi kasus dengan pengumpulan data menggunakan wawancara mendalam, kemudian pemilihan informan menggunakan purposive sampling atau criterion-based selection. Dalam penelitian ini, informan adalah redaktur pwти.co, sedangkan observasi dilakukan dengan melihat secara teliti ruang redaksi pwmu.co. Hasilnya penelitian ini menunjukkan bahwa pengelolaan media komunitas Muhammadiyah yang dilakukan oleh pwmu.co mengedepankan prinsip jurnalisme warga dan sukarela untuk menyelesaikan pekerjaan mereka dalam mengumpulkan berita. Wartawan media komunitas ini adalah para jurnalis warga yang berasal dari warga Muhammadiyah dan mereka dilatih melalui serangkaian workshop oleh redaktur pwmu.co.
\end{abstract}

Kata Kunci: Media Komunitas Daring, Jurnalisme Warga, Kesukarelaan, Muhammadiyah.

\section{Introduction}

The internet has immensely integrated technology into social lives. Technological integration into society will show interactions that explain the advancement of technology. The integration taking place in retaining the flexibility for defining social influence would seem technically inflexible up to a point. Consequently, the integration

Article History: Received December 21, 2018; Revised July 21, 2019; Accepted July 23, 2019; Published July 30, 2019 
will still be unpredicted. The interaction between technology and integration will simultaneously show the processes of adaptation and inflexibility, and technology will still have a role in the very core of society and cannot arbitrarily be transformed into solutions for every problem of society. Therefore, for understanding social effects of technology, specifically for understanding how social and cultural principles impact technology in terms of a model, experts have developed Social Construction of Technology (SCOT) or 'Konstruksi Sosial Teknologi' in Bahasa (official Indonesian language) (Kartika Sari, 2015).

In this context, as a progressive Islamic organization, Muhammadiyah does not ignore the importance of integrating technology upon its ' $d a$ ' wah' (missionary endeavor). When the era of print media commenced expanding to Indonesia in the 1900s, Muhammadiyah instantaneously appropriated that trend into its ' $d a$ ' $w a h$ ' program with the publishing of 'Suara Muhammadiyah' (Muhammadiyah Voice), a magazine that till this time, after more than a century, still consistently operate. Moreover, when the internet has started to be increasingly popular, Muhammadiyah addressed it by releasing websites as its ' $d a$ ' $w a h$ ' media. One of the most appealing uses of the internet, which is digital and online, for spreading Islam in Muhammadiyah's environment is run by pwmu.com, a community media organized by The Regional Office of Muhammadiyah ('Pengurus Wilayah Muhammadiyah' (PWM)) East Java.

As regards community media, (Pawito, 2007), in 'Media Komunitas dan Media Literacy' (Community Media and Media Literacy) observed that community media is a kind of media, whether printed or electronic, which is present in a particular society or community. It has several essential characteristics: 1) having a limited scope (local), 2) showing contextual content related to the communities' conditions, and 3) the organizers and the markets come from the same community and do not make a capital gain as the primary purpose of their service. The problem stemming from community media is its capability to maintain the sustainability of publications inexorably. Classical issues that typically turns to be the problem is lack of fund for that activity.

However, to some extent, the limited scope of community media is exceptionally open for further discussion considering the potency of the community to transcend any geographical locality by using the internet to the utmost. Therefore, the development of online community media run by Muhammadiyah literary activists in the nowadays context could be seen as the answer of Muhammadiyah towards millennial generation who is more familiar with the digital platform than with the old printed media. Millennials are actively using social media as one of their favorite way to express their aspirations. In line with the internet development mentioned, Muhammadiyah's community media also actively share their contents through social media. However, they still call for a unique position compared to the other mainstream traditional and online media for gaining more advantages.

The breakthrough then is discovered by empowering and inviting their members to voluntarily join in the news-making process, or in short, by performing citizen journalism. One of the advantages of citizen journalism is its capability in finding the information out, especially if the information comes from a society which inclines to be objective (Zaenudin, 2012). In addition, citizen journalism is presented for covering audiences' needs towards a wide range of information that cannot be provided merely by general mass media or mainstream media. The credibility of mass media that tend to be doubted lately makes citizen journalism be one of the preferred alternatives for the people to gain a diverse range of information (Yustitia, 2016). 
The place of people in citizen journalism is not only participating as consumers of contents production, as what happens in traditional media, but also as tools of production, as well as content distributors. Indeed, in a specific condition, people could be a part of developing the contents. Furthermore, what people do when producing contents and spreading it in citizen journalism is perceived as voluntarily act and is not based on profitoriented motives, such as earning money, gaining influence, or other economical-politic backgrounds (Nasrullah, 2012).

This paper will illustrate how citizen journalism has a role as the activator of Muhammadiyah online digital community media, which, in this case, is demonstrated by investigating pwnu.co. Pwnu.co is chosen since, compared to other Muhammadiyah's community media, it is one the fastest in updating the news, one of the most unique in the style of writing, and one of the most captivating in the template choices. The paper will approach the case using the optic of media management which roles as an inquiry into problems relating to the function of general management, leadership, content productions, marketing, human resources management, technological management, organization culture, and so on (Rahayu, 2010). It would help to examine, in the era of technological development, how media management adapt to the immense of information in the significant data era; how media management face the market changes in the digital era; and how media management should be more adaptive toward new policies and regulation on the internet in the framework of political and social context. Additionally, efficiency and affectivity would be considered as the general method to measure organizational work (Morissan, 2009).

In Indonesian context, this work will be essential since it apparently carries on previous research regarding citizen journalism which still focuses on the relationship between citizen journalism and weblog, as what has been done by (Yustitia, 2016), (Sukmono, 2012), (Zaenudin, 2012), (Putri, 2012) and (Nasrullah, 2012) to the roles of citizen journalism in online community media; (Loisa, Susanto, Junaidi, \& Loekman, 2019) to the relation between cyber media, government and news on diversity; (Darmadi, 2017) to new media as a global culture source for children and teenage media literacy.

\section{Methodology}

The research used the positivist paradigm. In the paradigm, the researcher should take a distance with reality and not interfere with the object study. That is to say, the researcher should be objective in the research. Specifically, the method used in the research was a case study with an single case. The focus of the research was a field study, particularly on the practice of online journalism that is conducted by pwmu.co. In addition, text analysis was performed by observing the content of pwmu.co to complete the data. The paradigm was materialized with these following steps:

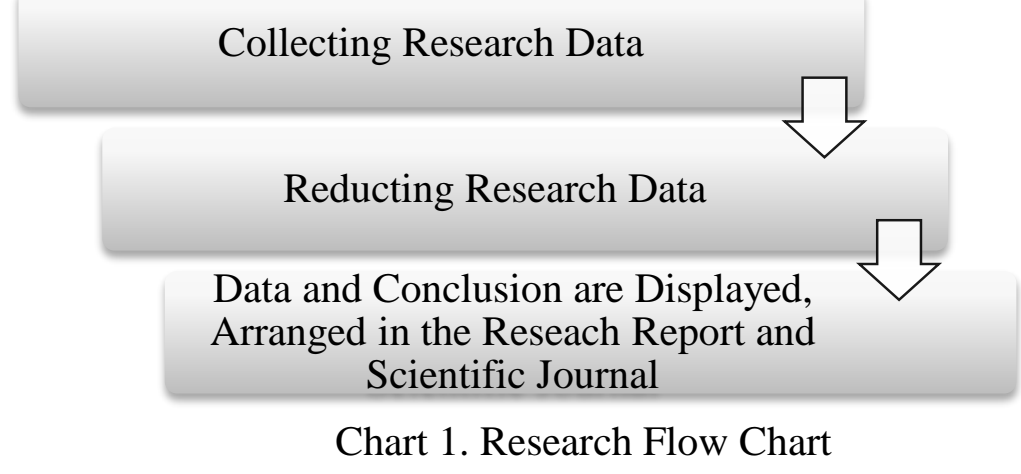

Citizen Journalism and Online Community Media ... (Filosa Gita Sukmono) 
The data collection was performed with in-depth interviews, observation, and literature review. The interview here was conducted in flexible and open ways, informal, without rigorous structure, and able to be repeated to the informant. The questions were arranged with an interview guide, and it became a priority in the interview process. After that, the guide could be expanded, developed, and modified for gaining more in-depth and unpredicted information. For accuracy, the answer will be written down (Neuman, 2000). The informants were chosen with purposive sampling method and criterion-based election. In this research, the informants were the editors of online community media under the Regional Office of Muhammadiyah (PWM) East Java while the observation was conducted carefully by discerning the editorial rooms of pwnu.co and the editorial process which took place in the same rooms. The results were recorded in the field note. The literature review was conducted by analyzing various works of literature regarding media management and Muhammadiyah citizen journalism.

The data reduction in the research was a part of the process' selection, simplification, and abstraction of the data taken from the interview record and field note. The data display was considered as a $\operatorname{cog}$ of the organizational information and description in the form of narration to enable the research conclusion could be finished although the conclusion needs to be verified in order to make the report adequately reliable. In that case, specific repetitions were necessary for ensuring and tracking down the result in the appropriate way. Verification could also be carried out by replicating the other data developing the exactitudes so that the conclusion could be stronger and entrusted (Sutopo, 2000).

The researcher discriminated various data that was collected from their visit to the Regional Office of Muhammadiyah (PWM) East Java, including from observation and direct interview with the editors of the community. The reduction data process also discussed the result from the field concerning Muhammadiyah community media and other references in the form of books and journals regarding community media and digital media. Finally, after the reduction data process, the researcher can draw a conclusion that can be made to be a model for citizen journalism movement in the Muhammadiyahs' online media.

\section{Results and Discussion}

The History and the Development of pwmu.co

A community media owned and organized by the Regional Office of Muhammadiyah (PMW/'Pengurus Wilayah Muhammadiyah') East Java is pwmu.co. Having owned and organized pwmu.co, PWM East Java also has published a monthly magazine called 'Matan.' The existence of 'Matan' indicates that in the East Java branch the literation rate is considerably high.

Compared to other Regional Office of Muhammadiyah in Indonesia, Regional Office of Muhammadiyah East Java actively publishes monthly magazine. Mostly, the Regional Office of Muhammadiyah prefers not to publish it. They tend to be subscribing to Suara Muhammadiyah as the official magazine published by Central Board of Muhammadiyah. Regional office of Muhammadiyah East Java, on the other hand, opts for publishing 'Matan' Magazine as well as subscribing to 'Suara Muhammadiyah'. It indicates that the Regional office of Muhammadiyah East Java realizes the importance of media as opposed to other Regional Office in other provinces. 


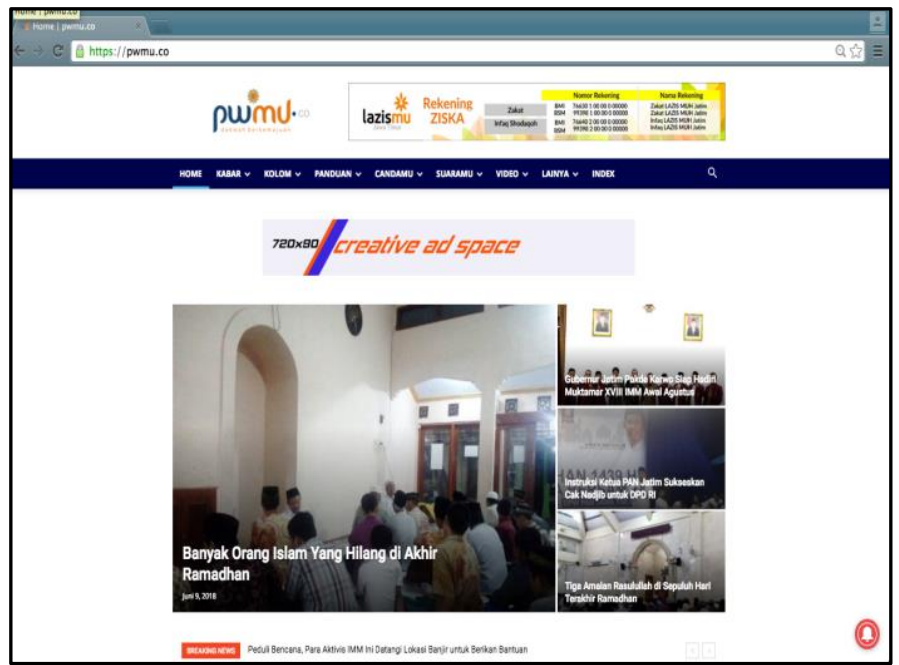

Picture 1. Home Page of pwmu.co

The idea behind the establishment of online community media for Muhammadiyah's member is founded upon some reasons. Firstly, the official online community which is organized by Muhammadiyah Central Board ('Pengurus Pusat' (PP) Muhammadiyah), namely muhammadiyah.id, is considered as not up-to-date in updating news. Secondly, the template in sub-domain for Muhammadiyah East Java is considered as not captivating. Thirdly, there is a massive urge to display news regarding Muhammadiyah to the public with casual language. Some of the members opined that the language style, which is too formal, would not be attractive for recent readers. Finally, there is some reservation regarding the position of Muhammadiyah in the field of online news, compared to other Islamic organizations, such as Nahdlatul Ulama (NU) and Salafy.

Although it is left behind, as opposed to the other internet-based community media organized by other Islamic organization, pwmu.com which established since 2016 is expected to compete in the internet discourse, at least in the Google index. That hope now becomes more challenging since Google, with its algorithm, makes the priority list based on the frequency of the visitors of the web.

Structurally, in the PWM East Java, pwmu.co is under the division of information and communication ('Lembaga Informasi dan Komunikasi'/LIK) and not in the house of literature and information ('Majelis Pustaka dan Informasi'/MPI). Typically, in the structure of Muhammadiyah organization, whether in the office center or the branch offices, community media is run by MPI. However, only in East Java, Muhammadiyah's community media is not organized by MPI. This division occurred since MPI is perceived to have a different scope with journalism. MPI focuses on organizing pieces of literature. Journalism then is the duty of LIK.

In terms of advertisement, pwmu.co has not attempted it seriously. There are only some institutions which already put their promotions there, namely 'Laziz Muhamadiyah' (charity institution), 'SMA Muhammadiyah 2 Sidoarjo' (Muhammadiyah High School 2 Sidoarjo), and 'Komisi Pemilihan Umum Jawa Timur' (East Java General Election Commission). There is an opportunity for the site to have support from AUM (Muhammadiyah's division of social-entrepreneurship), but since there is still no division in charge to organize the relationship, it is still in the process. Pwmu.co, therefore, only focuses on the editorial management lately. Lack of attention for the advertisement is acceptable, considering the mission of the site is for service and not for achieving capital 
gain. However, it does not say that community media does not look for takings. Takings that are earned by community media could be utilized for the media's development itself.

As to the viewers, the number of daily viewers of pwmu.co accounted for 9.039 in 2017, and in January 2018, just a month, the viewer comprises 480.031. However, the number is still well under the expectation of the editors of pwmu.co which target 30.000 viewers per year.

For increasing the total number of visitors, pwmu.co exhausts social media, whether officially with the account of pwmu.co or privately with the account of the journalist and editors. Facebook is the main concentration of pwmu.co. Its fan page has already gained around 130.000 likes. However, the result is not symmetrical with what happened to pwmu.co's followers on Twitter. The editors announced that Twitter has not been maximalized seriously because of the lack of human resources. It then inevitably becomes one of the primary attention of the editors of pwmu.co since, in this era of millennial, social media has powerful and significant impacts for sharing information, which in this case, sharing news of pwmu.co.

Regional Office of Muhammadiyah East Java performed the adaptive process by utilizing online media as communication media. Regional Office of Muhammadiyah East Java realized that media consumption is done often through digital media. That being said, they does not leave printed media. They still regularly publish Matan magazine every month. This is because the older generation is convenient for reading printed media.

The development of the internet in Indonesia started around the beginning of post1998. The freedom of press commenced since 1998 had opened the way for many mass media. The Internet has grown to be a popular platform for the media industry, organization, and community. (Tapsell, 2008) mentioned that media digitalization indeed could create super oligarchy media. More prominent media corporations have more probabilities of being more significant since digitalization gives them a chance to broaden their scopes. Media digitalization requires a higher level of capital in terms of infrastructure multiplatform so that smaller companies will put up with the investment baked up by digital media mogul. As a result, digitalization prompts the industry to be more concentrated and a place for the elites to exert their power. However, with this in mind, digital technology also enables the citizen to spread and share their ideas.

Pwmu.co can be deemed to be society effort to publish the news and share opinions that cannot be found in the typical mainstream media occupied by big corporations. Compared to those institutions, pwmu.co clearly cannot keep up with the amount of capital. However, pwmu.com does own advantage that is not owned by the media controlled by media mogul, namely higher potency of the number of reader and its militancy among Muhammdiyah people. It is indicated by the number of pwmu.co newslinks that is spread to the WhatsApp group by Muhammadiyah people. This spreading is pwmu.co free advertisement to gain a higher number of readers.

Media Management of pwmu.co's Citizen Journalism

The editors of pwmu.co are mainstream media's journalists who have Muhammadiyah background. They are part-timers. Therefore, the competency of the journalists of pwmu.co could be acknowledged adequate for journalism works. Socially, the existence of pwmu.co is an attempt to gather Muhammadiyah journalists, which is dispersed in various media companies. The editorial office of pwmu.co is located in the same building with the PWM East Java on Jl. Kertomenanggal IX, Dukuh Menanggal, Gayungan, Surabaya, East Java. That street is not separately far from the main road in Surabaya, Jl. Ahmad Yani. 
Having started from the reservation regarding the lack of Muhammadiyah news and the activities organized and run by Muhammadiyah, even the activities of Muhammadiyah's community media itself, pwmu.co developed citizen journalism in a collective and organized way. Pwmu.co's journalists are volunteers who come from Muhammadiyah members and have an interest in journalism. In order to be capable of being citizen journalists, they are facilitated with workshops which are named with 'kopidarat'.

The volunteers of pwmu.co frequently come from Muhammadiyah socioentrepreneurship division (AUM), especially from the sub-division of education and independent organization. The chief editor of pwmu.co describes the process for coaching those volunteers:

"In the first Kopi-darat conducted in July 2016, we could gather 125 participants. Those people were gathered using the network of MPI which openly announced to anyone wishing to be a contributor on pwmu.co... The second kopi-darat was conducted in March 2017 with 284 participants. The content of the workshop was the technique for writing, such as how to write decent news for online media. For example, if there is a speech of a public figure, what should be announced is not the figure but the content. For raising the motivation of the participant during the workshop, the participant whom his journalism work was selected will be given a set of a cell phone as a gimmick" (Muhammad Kholid, Chief Editor of pwmu.co, interview July 2, 2018).

After participating in the workshop, the participants are officially registered as the citizen journalists and hopefully could be active in sending news. For making the coordination easier, the editors of pwmu.co create a Whatsapp group for citizen journalist. Through that Whatsapp group, the editors provide on-going coaching to the volunteers who become the journalists of pwmu.co to improve their competencies in writing news.

Furthermore, the occurrence of the Whatsapp group is hugely utilized for coordinating and educating the contributors of pwmu.co. The group consists of 248 members and based on editors' experience; the active contributors come from these three cities: Surabaya, Sidoarjo, Gresik, and Malang. However, there is still a selection process for being the member of the Whatsapp group, namely by sending news at least three times to the editors.

The news sending process which is carried out by citizen journalist of pwmu.co is sent to the Whatsapp number of the editorial administrator via Whatsapp text. The administrator then will distribute the news to one of the editors. In the organization structure of pwmu.co, six editors are listed. For news containing sensitive content, such as politics and religion, it will be selected through the gatekeeping method directly edited by the chief editor. If the data which is sent by the contributor is not adequate, editors will directly call the contributor without mediated by the administrator. The uploading process could be conducted in several places, and mainly it is in the office of Muhammadiyah East Java, editor house, or other internet-access location. Mostly, the uploading process is done in the evening.

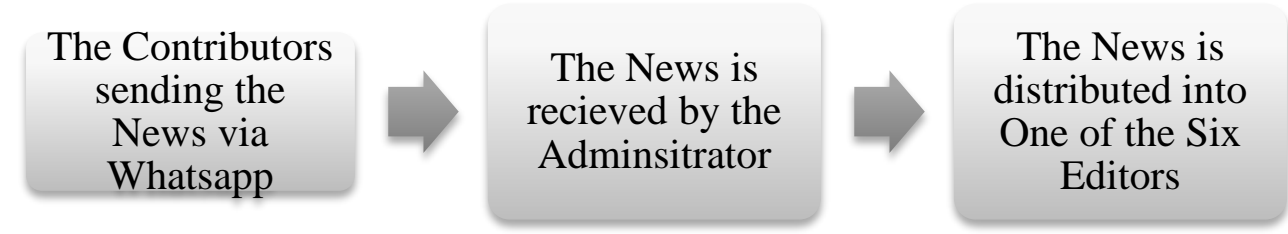

Chart 2. The News sending process from the Contributors 
The second news source is gained by tracking down pictures' activities, which are spread to many Whatsapp groups in Muhammadiyah East Java's environment. The tracking down of the news is conducted by selecting Muhammadiyah pictures activities which are participated in by the officers of PWM East Java. If the picture is considered having journalistic value, the editors will track the sources and then interview the people who are involved in those activities.

The next news source is writings sent by the officers of PWM East Java. One of the strengths of the PWM East Java is the passion and competency in writing. If there is an activity, the officers of PMW East Java will write news about the activities they are followed and subsequently send it into pwmu.co. There is some news which could be immediately displayed, but there is also news that needs some revisions.

The last news source is press releases. The editorial policies in the news publishing coming from the press release are by publishing the press lease having strong journalistic values. If the journalistic value is perceived as not strong enough, then the press release would not be uploaded as news.

One of the tendencies in the online mass media is the tendency to upload news using copy-paste method from other sites. Pwmu.co lies down rules stating that the copy-paste method is highly unacceptable. News coming from other sites would be allowed to be uploaded as long as the journalist of pwmu.co could contact the informants of the copied news to do re-interview. As what Bowman and Willis say, citizen journalism in the community media invariably emphasizes the participation. The purpose of the participation is for providing independent, trusted, accurate, and wide-scope of relevant information (Bowman \& Chris, 2003).

In the typical day, pwmu.co could upload twenty-three titles although the most productive day could reach forty-four titles. The chief editor of pwmu.co tells the story of how varied the qualities of the news which sent to the editors. "Concerning the quality, news displayed has various journalistic values. There is news having strong journalistic value, but there is also news that has weak journalistic value. The policies of the editors of pwmu.co to resolve that is by deciding five titles as the main news and the rest as the secondary” (Muhammad Kholid, Chief Editor of pwmu.co, Interview July 2, 2018).

It is also notable that PWM East Java gives significant attention to pwmu.co. One of the manifestations of the attention is by giving correction every time the officers find typos and substantial mistakes through short messages to the editors. It indicates that pwmu.co is read the sites carefully. The editors of pwmu.co thus try to be extremely careful in the news uploading, especially relating to religion and politics. News on religion will be discussed and consulted first with PWM East Java. Furthermore, the journalistic standard of carefulness of pwmu.co in the news on religious conflict is held sincerely. For instance, when there is a Muhammadiyah mosque in Malang which was forbidden to be used for praying, the editors would rectify the title and make it more acceptable and friendly. 


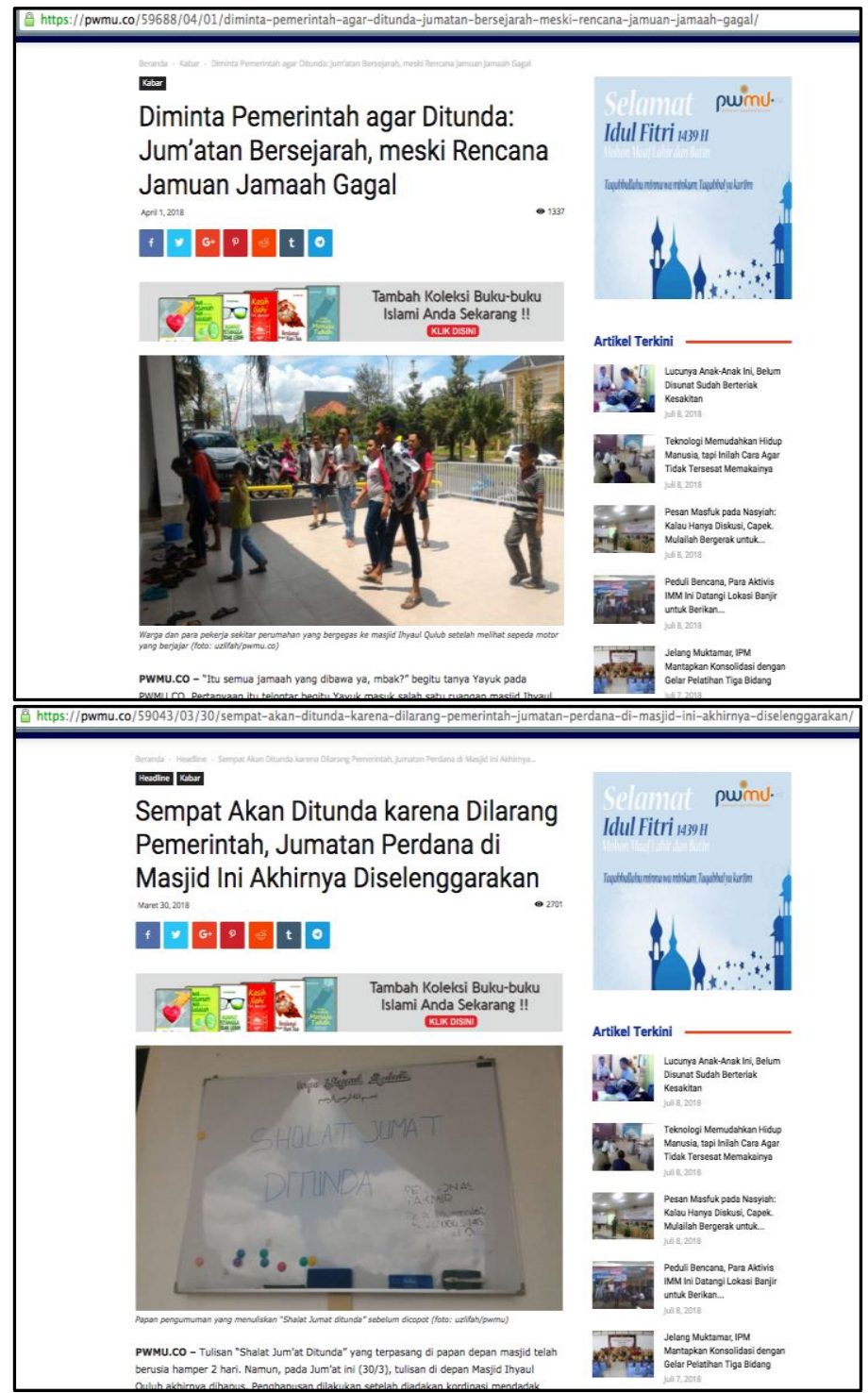

Picture 2. The News which the Titles have been rectified by the Editors of pwmu.co.

Generally, news that is read continuously is a religious topic, such as news that tells the rules of praying with the Indonesian language, Muslim converting story, or 'Fiqh'. On the other hand, news that always is the top trending in a specific time is the rules regarding uttering Christmas to Christians' friends and of 'Syaban' fasting.

\section{Conclusion}

An acute problem in community media is the problem of sustainability. With the advent of the internet, establishing a community media has been more comfortable and more inexpensive. As long as internet access is available, the content of media could be produced, shared, and consumed. Unfortunately, the problem of sustainability still could crop up because of the lack, or even the full-absence, of content produced in the editorial room. Pwmu.co is considered as an appealing editorial model for internet-based community media since it nicely succeeds in addressing the problem of sustainability. The reason behind this is that citizen journalists can be the activator in improving online community media in Muhammadiyah's environment.

The journalistic model developed by pwmu.co is citizen journalism with involving Muhammadiyah people to be the contributor. The journalistic competency of 
Muhammadiyah people is trained through a series of workshops which is conducted by the editors of pwmu.co. After participating in the workshop, Muhammadiyah people could officially claim themselves as citizen journalists of pwmu.co, and they are encouraged to actively sending news. The news sending is done by using various applications such as Whatsapp or e-mail. For improving the competency of the journalists, the editors create a Whatsapp group. The group plays as the place for discussing how news should be presented, as well as the place for the editors and journalists for sharing their experiences relating to journalism. The research has theoretically found that journalism practice developed by pwmu.co is citizen journalism that can be duplicated and modified for other community. In the middle of the competition with more significant corporations, community media should apply the model executed by pwmu.co to help them develop.

\section{Acknowledgments}

The authors would like to express his deep gratitude to Universitas Muhammadiyah Yogyakarta that has funded the research through the department funding scheme. We also would like to extend thanks to all informants from pwmu.co.

\section{References}

Bowman, S., \& Chris, W. (2003). We - Media: How Audiences are Shaping the Future of News and Information. US: The Media Centre American Press Institute.

Darmadi, M. (2017). Media Baru Sebagai Informasi Budaya Global -Membudayakan Literasi Media Internet Pada Anak Dan Remaja. Komunikator, 9(1), 39-48.

Kartika Sari, D. (2015). Penggunaan Media Sosial di Indonesia dalam Perspektif Social Construction of Technology. In I. Prijana Hadi, Information and Communication Technology dan Literasi Media. Surabaya: ASPIKOM, ASPIKOM Press, Universitas Katolik Widya Mandala Surabaya, Universitas Kristen Petra, Universitas Muhammadiyah Malang and Buku Litera.

Loisa, R., Susanto, E., Junaidi, A., \& Loekman, F. (2019). Media Siber, Aparat, dan Pemberitaan Keberagaman. Aspikom, 3(6), 1243-1254.

Morissan. (2009). Manajemen Media Penyiaran. Jakarta: Kencana Prenada.

Nasrullah. (2012). Komodifikasi Warga Dalam Ruang Citizen Journalism. Kawista, 2(2), $105-224$.

Neuman, L. (2000). Social Research Methods: Qualitative and Quantitative Approaches, 4th Edition. Boston: Allyn and Bacon.

Pawito. (2007). Media Komunitas dan Media Literacy. Jurnal Ilmu Komunikasi UAJY, 4(2), 167-177.

Putri, N. (2012). Gatekeeping Process Dalam Citizen Journalism Berkaitan Dengan Partisipasi Masyarakat Dalam Masyarakat Dalam Menyampaikan Informasi Lalulintas di Radio Idola FM Semarang. Jurnal The Messenger, 4(2), 35-42.

Rahayu. (2010). Ekonomi dan Manajemen Media: Perkembangan Kajian, Otokritik dan Eksplorasi terhadap Isu Lokalitas. In D. H. Rahmitasari, Potret Manajemen Media di Indonesia. Yogyakarta: Program Studi Ilmu Komunikasi UII and Total Media.

Sukmono, F. G. (2012). Ruang Publik Alternatif dalam Cyberspace. Komunikasi Makna, 2(2), 132-139.

Sutopo, H. (2000). Metode Penelitian Sosial Kualitatif. Solo: UNS Press.

Tapsell, R. (2008). Kuasa Media di Indonesia: Kaum Oligarki, Warga dan Revolusi Digital. Jakarta: Marjin Kiri. 
Yustitia, S. (2016). Citizen Journalism Melawan Mainstream Media. Jurnal The Messenger, 2(1), 1-9.

Zaenudin, H. N. (2012). Cermin Citizen Journalism di Indonesia. Observasi, 10(2), 103114. 